\title{
HET ONTWERP WET ADMINISTRATIEVE RECHTSPRAAK BELASTINGZAKEN
}

\author{
door Prof $\mathrm{Mr} \mathrm{H}$. J. Hellema
}

Op 20 September 1954 is bij de Tweede Kamer ingediend het ontwerp van Wet houdende een nieuwe regeling inzake belastingrechtspraak (zitting 1954-1955 no. 3704). Dit wetsontwerp beoogt de rechtspraak in belastingzaken over te brengen van de raden van beroep naar de gerechtshoven. Ter motivering van dit ingrijpend voorstel wordt er in de M.v.T. op gewezen, dat na de dertiger jaren de door de raden van beroep te hanteren rechtsstof in snel tempo is uitgebreid en dat de belastingheffing steeds meer gedifferentieerd is naar finantiële, sociale en algemeen-economische doelstellingen. Deze differentiatie, gevoegd bij de toeneming van de belastingdruk, noopte, zowel ter voorkoming van onbillijkheden als met het oog op het keren van misbruiken, tot het treffen van meer gedetailleerde regelingen dan in de vooroorlogse belastingwetten waren vervat. Het beheersen van het belastingrecht is dan ook een zware taak geworden. De rechtspraak in belastingzaken is evenwel onveranderd in handen gebleven van personen, die elders een hoofdfunctie vervullen. Dientengevolge voldeed deze rechtspraak niet altijd aan de eisen, die men er in redelijkheid aan kan stellen. De hoeveelheid te berechten zaken kon door een aantal raden niet meer tijdig worden verwerkt, terwijl een verantwoorde personeelsbezetting vele moeilijkheden met zich bracht. Vandaar dat wordt voorgesteld deze taak op te dragen aan de gerechtshoven.

Van deze combinatie van administratieve en gewone rechtspraak wordt verwacht, dat deze tot bevruchting en inspiratie op beide gebieden zal leiden en de eenheid van rechtspraak er door zal worden bevorderd. Voorts wordt gesteld, dat rechtspraak in belastingzaken - evenals in alle administatiefrechtelijke geschillen - in twee instanties zeker voldoende waarborgen biedt voor een deugdelijke berechting. In een administratiefrechtelijk geding begint men met een door de administratie bijeengebracht dossier, zodat anders dan in het civiele geding de feitelijke grondslag niet gelegd, doch hongstens gecorrigeerd behoeft te worden.

De gedachte om deze rechtspraak aan de rechtbanken op te dragen wordt verworpen op twee gronden: er zijn niet voldoende belastingdes kundigen om bij iedere rechtbank een belastingkamer te bezetten en zo zij er al waren, dan zouden ze geen volle dagtaak hebben.

Door de opdracht aan de gerechtshoven kan men zich tot een geringer aantal belastingdeskundigen beperken, derhalve - mede door de betere salariëring - hogere eisen stellen en het merendeel der zaken in enkelvoudige kamer afdoen.

Het is de bedoeling bij deze Kamer van het hof tevens onder te brengen de rechtspraak inzake de Successiewet, de registratie en de zegelwet en de rechtspraak, die nu nog door Gedeputeerde Staten wordt uitgeoefend en tenslotte de rechtspraak inzake de wet tot bevordering van de richtige heffing.

De Tariefcommissie zal echter blijven bestaan.

Omdat men vreest onder de juristen niet voldoende deskundige liefhebbers voor deze rechterlijke functie te vinden, zal gedurende een overgangsperiode van tien jaar, eventueel zo nodig met vijf jaar te verlengen, de mogelijkheid geopend worden om tot vice-president, raadsheer of

m a b blz. 258 
raadsheer-plaatsvervanger te benoemen candidaat-notarissen en degenen, die met goed gevolg examen in de belastingwetenschappen aan de rijks belastingacademie hebben afgelegd.

Ziehier de kern van het in de Memorie van Toelichting vervatte betoog.

Het wil mij voorkomen, dat de argumenten om de belastingrechtspraak naar de gerechtshoven te verplaatsen niet erg overtuigend zijn. De belastingrechtspraak is inderdaad zo belangrijk en zo ingewikkeld geworden, dat het gewenst is de rechtspraak op te dragen aan rechters, die deze taak niet als nevenfunctie uitoefenen, maar er zich ten volle aan wijden. Maar dat zou men ook kunnen bereiken door de Wet op de raden van beroep op dit punt te wijzigen. De aangevoerde argumenten om deze rechtspraak niet bij de arrondissements-rechtbanken - de normale eerste instantie - onder te brengen, zijn ten dele zwak, ten dele uiterst pijnlijk. Waneer niet bij iedere rechtbank een belastingkamer gewenst is, zou men zonder bezwaar het aantal rechtbanken, waar een dergelijke kamer wordt ingesteld, kunnen beperken.

Toegegeven wordt, dat de belastingrechtspraak kan volstaan met twee instanties. Welnu, wil men de belastingrechtspraak met de gewone rechtspraak combineren, dan behoort deze niet bij de appèlinstantie, maar bij de normale rechter in eerste instantie te worden ondergebracht. Het argument, dat men de raadsheren beter kan salariëren en daardoor ook hogere eisen kan stellen, is een pijnlijke erkenning, dat men de rechterlijke macht onvoldoende honoreert en nu in rangeninflatie zijn heil zoekt. Tegenover de gewone rechters kan men hier toch moeilijk anders dan een ongerechtvaardigde discriminatie in zien.

Belangrijker is echter de vraag of het inderdaad gewenst is de belastingrechtspraak met de gewone rechtspraak te combineren. Als enig argument daarvoor wordt aangevoerd, dat een uit elkaar groeien van burgerlijk recht en belastingrecht tot ongewenste consequenties zou voeren en dat het onderbrengen van de cassatie rechtspraak bij de Hoge Raad heeft geleerd, dat deze combinatie van administratieve en gewone rechtspraak tot bevruchting en inspiratie op beide gebieden heeft geleid. $\mathrm{Nu}$ kan men dit dankbaar erkennen en toch de vraag stellen of wat geldt voor de beperkte taak van de cassatierechter nu zonder meer ook op de rechtspraak in eerste instantie kan worden toegepast.

Hoe hoog men een grondige kennis van de uiteenlopende gebieden van het recht moge aanslaan en hoezeer men zich terecht kan verontrusten over de op ieder gebied van wetenschap en techniek voortschrijdende specialisatie, het valt nu eenmaal niet te ontkennen, dat het ondoenlijk is om de rechtswetenschap in haar geheel te beheersen. Specialisatie is dan ook een noodzakelijk kwaad. Zelfs het belastingrecht is te veel omvattend om het grondig te beheersen. Welke belastingdeskundige durft van zichzelf te verklaren, dat hij de wetten op de inkomstenbelasting, loonbelasting, vennootschapsbelasting, vermogensbelasting, omzetbelasting, de algemene wet en de successie-, registratie- en zegelwet, om van de vele andere wetten maar te zwijgen, behoorlijk onder de knie heeft?

Daar komt nog bij, dat men in de belastingrechtspraak de verplichte vertegenwoordiging niet kent, hetgeen de taak van de rechter uitermate verzwaart. De grondige schriftelijke en mondelinge toelichting van een rechtsgeschil door bekwame advocaten verlicht de taak van de rechter aanmerkelijk. Moet de rechter het zonder deskundige voorlichting doen, dan zal hij de materie veel beter moeten beheersen. 
Hoogenbergh heeft in het Nederlands Juristenblad 1955 pag. 293 de verplichte vertegenwoordiging door de balie in belastingzaken bepleit. Ook den Tex had zulks, hoewel veel minder positief ,reeds bepleit in zijn artikel over dit wetsontwerp in het Ned. Juristenblad 1954 pag. 953. Dit voorstel gaat mij in tweeërlei te ver. Enerzijds zijn er een groot aantal onbetekenende geschillen, die zonder bezwaar door de belastingplichtigen of hun niet academisch gevormde raadslieden kunnen worden behandeld, anderzijds zijn er tal van geschillen, die zo zeer bedrijfseconomisch of boekhoudkundig gebied liggen, dat de niet op deze gebieden gespecialiseerde jurist daarbij niet de best gequalificeerde vertegenwoordiger is.

Het wil mij dan ook voorkomen, dat in het ontwerp terecht is bepaald, dat de belanghebbende zich door een gemachtigde kan doen vertegenwoordigen, zij het dan ook dat het Hof de vertegenwoordiging door een bepaalde gemachtigde bij met redenen omklede beschikking kan weigeren. Zowel de belanghebbende als zijn gemachtigde kan zich doen bijstaan, maar voor de bijstand door andere personen dan een advocaat is toestemming van het gerechtshof nodig.

Op grond van het vorenstaande betwijfel ik ook of het wel zo wenselijk is om in een procedure, waarin men slechts één instantie heeft, behoudens cassatie, de enkelvoudige kamer als regel, de meervoudige kamer als uitzondering te stellen. Erkend moet echter worden, dat zowel partijen als de rechter zelf behandeling voor de meervoudige kamer kunnen vragen, waardoor het bezwaar voor een belangrijk deel wordt ondervangen.

$\mathrm{Nu}$ men er klaarblijkelijk aan twijfelt of men wel voldoende juristenbelastingdeskundigen zal vinden voor de bezetting van de belastingkamers van de hoven en daardoor genoodzaakt is geweest om bijwijze van overgangsmaatregel ook candidaatnotarissen en afgestudeerden van de rijksbelastingacademie toe te laten, rijst opnieuw de vraag of het een zo gelukkige gedachte is geweest om de belastingrechtspraak aan de hoven op te dragen. Volgens de wet op de raden van beroep moet hij, die de werkzaamheden der enkelvoudige kamer verricht, jurist zijn, maar in de meervoudige kamer kunnen ook niet juristen zitting hebben.

Is het nu een belangrijke verbetering, dat de wetgever de belastingrechtspraak op de duur uitsluitend in handen van juristen wil leggen? Het ligt voor de hand, dat men rechtspraak als een voor de juristen gereserveerd gebied beschouwd. Daar staat echter tegenover, dat de meeste juristen zich ver van het gebied van de belastingen hebben gehouden. Tracht men dit te verklaren door het feit, dat de belastingwetenschap nog zeer jong is en dat er eerst in de laatste decennia de behoefte gebleken is aan meer juridische bijstand in fiscale zaken, dan ben ik toch geneigd de vraag te stellen of men oorzaak en gevolg niet omdraait. De historie geeft ons talloze perioden van zeer hoge belastingen te zien en men kan de late ontwikkeling van een belastingwetenschap m.i. moeilijk anders verklaren dan uit een van nature bestaande tegenzin bij de juristen tegen het belastingrecht, weliswaar behorende tot het gebied van het recht, maar toch een grensgebied, dat raakt aan verschillende andere gebieden en dat zeker niet uitsluitend juridisch bekeken kan worden.

Het is wellicht gewaagd om in een orgaan, speciaal bestemd voor accountants te beweren, dat de mensen in het algemeen bijzonder weinig belangstelling voor cijfers hebben. Mogelijk is ook, dat de accountants juist deze stelling zullen beamen. Want is ook hun ervaring niet, dat er 
in ieder bedrijf slechts enkelen zijn, voor wie de taal der zo moeizaam door hen verzamelde en gegroepeerde cijfers werkelijk spreekt? Aan degenen, die geneigd zijn de juistheid van mijn bewering te betwijfelen, zou ik willen vragen eens de publieke belangstelling te vergelijken voor de behandeling van onze rijksbegroting en bijvoorbeeld het liftverbod.

Welnu, is de belangstelling voor cijfers in het algemeen niet groot, bij de jurist is deze naar mijn ervaring niet boven het gemiddelde. Onder jurist versta ik dan niet ieder die de meesterstitel draagt. Daarvoor hebben te velen deze studie gekozen, omdat het de minst moeizame wijze was om een academische titel te krijgen. Maar gelijktijdig echt wetenschappelijke belangstelling voor de rechtswetenschap en financiën is m.i. zeldzaam. Het is dan ook m.i. hier aan te wijten, dat de balie als geheel zich zo weinig met het belastingrecht heeft bemoeid. En het zal wel niet alleen mijn ervaring als docent zijn, dat het aantal juristen, dat werkelijke belangstelling heeft voor de bedrijfseconomische en boekhoudkundige problemen, gering is.

Onder deze omstandigheden is er toch wel wat voor te zeggen om de raden van beroep te laten voortbestaan en de mogelijkheid om hierin naast juristen ook andere belastingdeskundigen te kunnen benoemen, te handhaven. De jurist zal zich, wil hij voor rechter in belastinggeschillen in aanmerking komen, op andere dan juridische gebieden hebben te bekwamen. Maar zou de bedrijfseconoom en de accountant, die zich daarnaast tot het recht en het belastingrecht aangetrokken voelt en daar speciale studie van heeft gemaakt, niet een waardevol lid van de meervoudige kamer kunnen zijn?

De overgangsregeling, die nu in het ontwerp voorkomt, is m.i. weinig bevredigend. De bij de gratie van de overgangsregeling tot raadsheer in de belastingkamer benoembaren, zijn en blijven tweederangs raadsheren, want ze zullen niet kunnen deelnemen aan de bij de gerechtshoven gebruikelijke periodieke verplaatsing in een andere kamer. En omgekeerd brengt deze gebruikelijke roulering het gevaar mede, dat men raadsheren in de belastingkamer krijgt, die voor deze materie niets voelen en zich in de enkele jaren, dat zij in de belastingkamer zitten, zich daarin niet voldoende zullen inwerken. Een bezwaar, dat ook in het hierna te noemen request van de presidenten der gerechtshoven naarvoren wordt gebracht.

Is het dan niet beter om de bestaande raden van beroep te handhaven. maar het lidmaatschap dezer raden tot een volledige betrekking te maken en ook niet-juristen benoembaar te maken? Handhaaft men dan, dat berechting door de enkelvoudige kamer door een jurist moet geschieden, dan kan men juist bij de ingewikkelde belastingzaken, die voor de meervoudige kamer worden behandeld, van de speciale bekwaamheden van de niet-jurist profiteren en dan behoeft men zich ook niet te beperken tot de candidaat-notarissen en degenen, die de rijksbelastingacademie met succes volgden.

In deze raden behoeven deze deskundigen-niet-als-jurist-gequalificeerden zich ook niet als tweederangs figuren te beschouwen. Weliswaar kunnen zij niet tot voorzitter of alleen-zittend rechter worden benoemd, maar daartegenover staat het voordeel, dat zij in de meervoudige kamer alleen de interessante zaken krijgen. Het is wel tekenend, dat de presidenten van de Hoven unaniem tegen het opdragen van de belastingrechtspraak aan de hoven hebben geprotesteerd.

In een request aan de Minister van Justitie wordt er op gewezen, dat 
de belastingrechtspraak een geheel ander karakter heeft dan de gewone rechtspraak en zich ook in een andere sfeer pleegt af te spelen. De homogeniteit der colleges zal dan ook door instelling van belastingkamers nadelig worden beinvloed. De gerechtshoven zijn appèlcolleges, doch de belastingrechtspraak is rechtspraak in eerste aanleg. Rechtspraak door alleensprekende rechters is wezensvreemd aan de bij uitstek collegiale rechtspraak der Hoven. De presidenten spreken dan ook als hun mening uit, dat de belastingrechtspraak het best gediend zal zijn door haar toe te vertrouwen aan afzonderlijke fiscaalrechterlijke colleges. Terecht wijzen zij er voorts op, dat het in wezen hetzelfde is of de rechtspraak in handen blijft van afzonderlijke raden van beroep dan wel wordt opgedragen aan afzonderlijke belastingkamers van de Hoven. Het Voorlopig verslag van de Tweede Kamer over dit wetsontwerp is nog niet verschenen. Met belangstelling wachten we af hoe de reactie van het parlement op deze voorstellen zal zijn. De discussie zal zich wel volledig concentreren op de vraag of de rechtspraak zal worden opgedragen aan de gerechtshoven of aan afzonderlijke colleges en wie als rechter benoembaar zullen zijn, daar het wetsontwerp overigens zeer nauw aansluit bij de bestaande wet op de raden van beroep.

Naar ik meen zal ook de belangstelling van de meeste lezers van dit blad zich wel beperken tot deze punten en minder uitgaan naar de details, waarop het ontwerp afwijkt van de bestaande wet. Ik meen mij dus van beschouwingen daaromtrent te mogen onthouden. Voor degenen, die daarvoor wel belangstelling hebben, verwijs ik naar het hiervoor reeds genoemde artikel van den Tex en een beschouwing van Fray in het Weekblad der Belastingen no. 4221. 